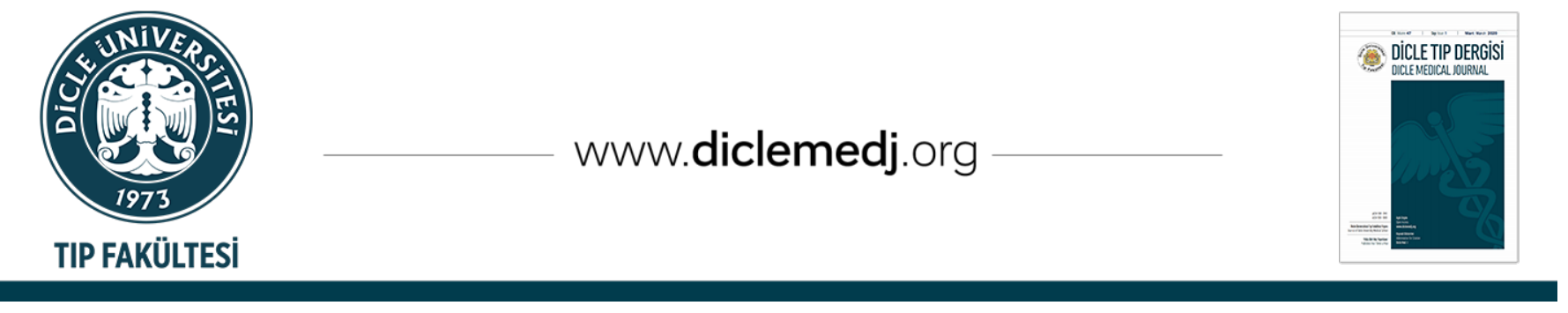

Original Article / Özgün Araştırma

\title{
Characteristics and the Emergency Department Cost of Tendon Injuries of the Hand
}

\author{
Afsin Ipekci ${ }^{(D)}$, Yonca Senem Akdeniz ${ }^{(D)}$, Cigdem Orhan ${ }^{(D)}$, Fatih Cakmak ${ }^{\text {1D }}$, Ibrahim Ikizceli 1 \\ 1 Department of Emergency Medicine, Cerrahpasa Faculty of Medicine, Istanbul University-Cerrahpasa, Istanbul, Turkey \\ 2 Emergency Room, Beylikduzu State Hospital, Istanbul, Turkey
}

Received: 12.06.2020; Revised: 21.08.2020; Accepted: 30.08.2020

\begin{abstract}
Objective: Hand injuries lead to high morbidity rate, and long-term labor loss due to their functional significance, and tendon injuries occur in more than $50 \%$ of patients even with small lacerations. We aimed to evaluate the characteristics and the emergency department cost of tendon lacerations of hand injuries.

Methods: The study's data were obtained retrospectively by digital scanning of the files of patients admitted to the ED with an isolated hand injury from June 2014 to June 2016. The characteristics of patients and the emergency department costs from billing information were recorded and analyzed.

Results: A total of 132 patients included. The mean age of the patients was $33.32 \pm 13.03$ years, and $83.3 \%$ were male. The vast majority of injuries occurred at home (64.4\%), more than half of the injuries were caused by puncture-cutting tools (54.5\%), and the most injured location was the flexor area (56.8\%). The mean of the number of injured tendons were $2.50 \pm 2.26$ tendons. The average cost of tendon injuries was 1.065,34 $\pm 828,90 \mathrm{TL}$, and the flexor tendon injuries had the highest cost average.

Conclusion: Tendon injuries affect especially the young adult male population. The ED expenses of tendon injuries are high enough to mind and even more evident when further hospital beds and following physical therapy costs and the costs related to the labor loss were added.
\end{abstract}

Keywords: Hand, tendon injuries, cost, emergency department

DOI: 10.5798/dicletip.799923

Correspondence / Yazışma Adresi: Afsin Ipekci, Department of Emergency Medicine, Cerrahpasa Faculty of Medicine, Istanbul University-Cerrahpasa, Istanbul, Turkey, e-mail: afsin.ipekci@istanbul.edu.tr 


\section{El Tendon Yaralanmalarının Özellikleri ve Acil Servis Maliyeti}

$\ddot{0} \mathbf{z}$

Amaç: El yaralanmaları fonksiyonel özelliklerinden dolayı yüksek oranda morbiditeye ve uzun süreli iş gücü kaybına neden olur. Tendon yaralanmaları bu hastaların \%50'sinde küçük kesilerde bile meydana gelir. Tendon yaralanmalarının karakteristik özellikleri ve acil servis maliyetlerini analiz etmeyi amaçladık.

Yöntemler: Bu çalışma izole el yaralanması ile Haziran 2014 ile Haziran 2016 tarihleri arasında acil servise başvuran hastaların dosyalarının geriye dönük taranması ile gerçekleștirildi. Hastaların ve tendon yaralanmalarının karakteristik özellikleri ve faturalarından acil servis maliyetleri kayıt ve analiz edildi.

Bulgular: Toplam 132 hasta dahil edildi. Hastaların yaş ortalamaları 33.32 \pm 13.03 yıl ve \%83.3'ü erkekti. Yaralanmaların büyük çoğunluğu evde (\%64.4) meydana gelmişti ve yaralanmaların yarısından fazlasının nedeni kesici-deli aletler idi (\%54.5). En sık yarlanma fleksör yüzde (\%56.8) idi. Yaralanan tendon sayısı ortalaması 2.50 2.26 tendon idi. Tendon yaralanmalarının ortalama acil servis maliyeti 1.065,34 $\pm 828,90 \mathrm{TL}$ ve fleksör tendon yaralanmaları en yüksek maliyete sahipti.

Sonuç: Tendon yaralanmaları özellikle genç erişkin erkekleri etkiler. Tendon yaralanmalarının acil servis maliyetleri yeterince yüksektir ve buna yatak ücreti, fizik tedavi maliyeti ve iş gücü kaybının maliyeti eklendiğinde daha belirgin hale gelir.

Anahtar kelimeler: El, tendon yaralanmaları, maliyet, acil servis.

\section{INTRODUCTION}

Hands are one of the most important organs that help to perform activities of daily living and are also the most active and the most injured part of the upper limb ${ }^{1}$. Hand injuries account for $6.6 \%$ to $28.6 \%$ of all bodily injuries and $28 \%$ of skeletal muscle system ${ }^{2}$. Hand injuries lead to high morbidity rates and long-term labor loss due to their functional significance ${ }^{3}$.

Tendon injuries, in general, are relatively common, affecting up to 1 in 2000 people each year, with injuries specific to the hand and wrist occurring in up to 1 in 2700 people each year ${ }^{4,5}$. Of all hand injuries, tendon injuries occur in more than $50 \%$ of patients with small lacerations and over $90 \%$ in those with a deep injury after a small laceration6. Even minor lacerations to the hand may involve the tendons resulting in some level of disability and a concomitant socio-economic impact ${ }^{7}$. Collecting, analyzing, and taking necessary security, equipment, and training measures of data belonging to injuries that cause this level of labor loss and cost in society is extremely important 8 .

We aimed to analyze the characteristics and emergency department (ED) cost of patients with tendon injuries, who applied to the emergency department with an isolated hand injury and to show the tip of the iceberg.

\section{METHOD}

It was approved by the decision of Istanbul University Cerrahpasa Faculty of Medicine Ethics Committee No. 39354. Data of the were study obtained by retrospective digital scanning of the files of patients who applied to the ED of a university hospital from June 2014 to June 2016 after the ethical committee approval. Patients with hand injuries, including tendon injuries, treated in and discharged from the emergency department, were included in the study. Patients with superficial injuries, without tendon injuries, admitted to other services, and with multiple injuries were excluded because they would affect cost analysis. The patients' ED expenses included examination cost, laboratory cost, imaging cost, and medical intervention costs performed in the ED, such as drug infusion, intravenous access, dressing, and tendon repair. Age, gender, etiology of injury, location of the injury, injured zones, and the number of damaged tendons recorded. Accompanying injuries such as none, nerve, bone, and vessel divided into groups 
recorded and analyzed. The emergency department expense of the patients was obtained from billing as Turkish Lira (TL).

\section{Statistical Analysis}

SPSS 24 for Windows statistical software was used. Kolmogorov-Smirnov test was used to check for normal distribution of study variables. Descriptive statistical methods were used to analyze demographic and clinic data. Independent Samples T-test was used to a comparison of two groups, and a One-way ANOVA test was used to the comparison of multiple groups with a normal distribution. Mann-Whitney U test was used to a comparison of two groups, and the Kruskal-Wallis test was used to a comparison of multiple groups that did not fit the normal distribution. $\mathrm{P}$ value $<0.05$ was considered as statistically significant.

\section{RESULTS}

A total of 132 patients with tendon injuries who underwent followed-up, treated in, and discharged from the ED were included in the study. The mean age of the patients was $33.32 \pm 13.03$ years, and $83.3 \%$ were male. The right hand was injured in $56.1 \%$ of patients. The mean age of male patients was $33.84 \pm 12.86$ years, and the mean age of female patients was $30.72 \pm 13.87$ years $(p=0.308)$.

The vast majority of injuries occurred at home (64.4\%), at the workplace (18.9\%), and on the street (15.2\%). Injuries occurred more common at home $(\mathrm{n}=65,59.1 \%)$, at workplace $(\mathrm{n}=24,21.8 \%)$, and on the street $(n=19,17.3 \%)$ in male population, while injuries occurred more common at home $(n=20$, $90.6 \%$ ) in female population. More than half of the injuries were caused by puncture-cutting tools (54.5\%). Other common causes of injury were glass cut $(20.5 \%)$, press machine $(7.6 \%)$, and spiral machine $(6.1 \%)$. The puncture-cutting tools $(n=54$, $49.1 \%)$, glass cut $(\mathrm{n}=24,21.8 \%)$, press machine $(\mathrm{n}=9,8.2 \%)$, and spiral machine $(\mathrm{n}=8,7.3 \%)$ were more common causes in male population however, puncture-cutting tools $(\mathrm{n}=18,81.8 \%)$ and glass cut $(n=3,13.6 \%)$ were more common causes in female population. The flexor area (56.8\%) was the most injured area in total and in both populations. The extensor zone $(39.4 \%)$ was in second place, and both zones $(3.8 \%)$ were in third place. The flexor area had the highest cost average (Table 1).
Table I: Characteristics and ED cost averages of patients

\begin{tabular}{|c|c|c|c|c|}
\hline Gender & $\mathbf{n}$ & $\%$ & Cost in TL, (mean \pm SD) & $\mathbf{p}$ \\
\hline Male & 110 & 83.3 & $857,19 \pm 868,60$ & \multirow{2}{*}{0.113} \\
\hline Female & 22 & 16.7 & $810,14 \pm 660,70$ & \\
\hline \multicolumn{5}{|l|}{ Hand } \\
\hline Right & 74 & 56.1 & $903,60 \pm 919,11$ & \multirow{2}{*}{0.382} \\
\hline Left & 58 & 43.9 & $780,17 \pm 698,96$ & \\
\hline \multicolumn{5}{|l|}{ Location } \\
\hline Home & 85 & 64.4 & $863,38 \pm 832,46$ & \multirow{4}{*}{0.666} \\
\hline Workplace & 25 & 18.9 & $921,85 \pm 987,51$ & \\
\hline Street & 20 & 15.2 & $761,86 \pm 618,87$ & \\
\hline School & 2 & 1.2 & $220,50 \pm 147,78$ & \\
\hline \multicolumn{5}{|l|}{ Etiology } \\
\hline $\begin{array}{l}\text { Puncture- } \\
\text { cutting tool } \\
\text { injuries }\end{array}$ & 72 & 54.5 & $684,64 \pm 612,36$ & \multirow{9}{*}{0.757} \\
\hline Glass cut & 27 & 20.5 & $883,47 \pm 1.057,57$ & \\
\hline $\begin{array}{l}\text { Press } \\
\text { machine } \\
\text { injuries }\end{array}$ & 10 & 7.6 & $1.098,18 \pm 1.040,18$ & \\
\hline $\begin{array}{l}\text { Spiral } \\
\text { machine cut }\end{array}$ & 8 & 6.1 & $749,59 \pm 877,28$ & \\
\hline Saw cut & 5 & 3.8 & $1.129,96 \pm 1.274,36$ & \\
\hline Door crush & 5 & 3.8 & $1347,98 \pm 1.130,36$ & \\
\hline $\begin{array}{l}\text { Pedestrian } \\
\text { accident }\end{array}$ & 3 & 2.3 & $1.035,00 \pm 884,37$ & \\
\hline Animal bite & 1 & 0.8 & 382,96 & \\
\hline $\begin{array}{l}\text { Firearm } \\
\text { injuries }\end{array}$ & 1 & 0.8 & $1.248,98$ & \\
\hline \multicolumn{5}{|l|}{ Injured areas } \\
\hline Flexor & 75 & 56.8 & $1.332,18 \pm 912,45$ & \multirow{3}{*}{$<0.001^{*}$} \\
\hline Extansor & 52 & 39.4 & $458,82 \pm 474,40$ & \\
\hline Both & 5 & 3.8 & $1.070,38 \pm 977,76$ & \\
\hline Total & 132 & 100 & $849,34 \pm 28,90$ & \\
\hline
\end{tabular}

*: Significant difference only between flexor and extansor area

More than half of the injuries were seen in the third, fourth, and fifth decade. Injuries in male gender were more common in third $(n=31,28.2 \%)$ and fifth $(\mathrm{n}=27,24.5 \%)$ decade however, injuries in female 
gender were more common in third $(n=9,40.9 \%)$ and fifth $(n=5,22.7 \%)$ decade. Puncture-cutting tool injury was the most common cause in all decades (Table 2).

Table II: Characteristics of patients according to decades of age.

\begin{tabular}{|c|c|c|c|c|c|c|c|c|}
\hline & $\begin{array}{l}0-9 \\
n=4\end{array}$ & $\begin{array}{l}10-19 \\
n=15\end{array}$ & $\begin{array}{l}20-29 \\
n=40\end{array}$ & $\begin{array}{l}30-39 \\
n=27\end{array}$ & $\begin{array}{l}40-49 \\
n=32\end{array}$ & $\begin{array}{l}50-59 \\
n=12\end{array}$ & \begin{tabular}{|c|}
$60-69$ \\
$n=2$
\end{tabular} & Total \\
\hline \multicolumn{9}{|l|}{ Gender } \\
\hline Male & 3 & 12 & 31 & 25 & 27 & 10 & 2 & 110 \\
\hline Female & 1 & 3 & 9 & 2 & 5 & 2 & - & 22 \\
\hline \multicolumn{9}{|l|}{ Location } \\
\hline Home & 4 & 11 & 27 & 14 & 20 & 8 & 1 & 85 \\
\hline Workplace & - & - & 4 & 7 & 10 & 3 & 1 & 25 \\
\hline Street & - & 2 & 9 & 6 & 2 & 1 & - & 20 \\
\hline School & - & 2 & - & - & - & - & - & 2 \\
\hline \multicolumn{9}{|l|}{ Etiology } \\
\hline $\begin{array}{l}\text { Puncture-cutting } \\
\text { tool injuries }\end{array}$ & 3 & 8 & 26 & 12 & 15 & 7 & 1 & 72 \\
\hline Glass cut & - & 5 & 9 & 7 & 4 & 2 & & 27 \\
\hline $\begin{array}{ll}\text { Press machine } \\
\text { injuries }\end{array}$ & - & - & 2 & 3 & 5 & - & - & 10 \\
\hline $\begin{array}{ll}\text { Spiral machine } \\
\text { cut }\end{array}$ & - & - & - & 1 & 4 & 2 & 1 & 8 \\
\hline Saw cut & - & & & 3 & 1 & 1 & - & 5 \\
\hline Door crush & 1 & 1 & 2 & & 1 & - & - & 5 \\
\hline $\begin{array}{l}\text { Pedestrian } \\
\text { accident }\end{array}$ & - & - & 1 & - & 2 & - & - & 3 \\
\hline Animal bite & - & 1 & - & - & - & - & - & 1 \\
\hline Firearm injuries & - & - & - & 1 & - & - & - & 1 \\
\hline
\end{tabular}

The flexor zone 5 injuries were seen in $18.2 \%$ of patients thereafter, flexor zone 2 and extensor zone 6 injuries were seen in 16.2\% and 13.6\% of patients (Table 3).
Table III: The number of injured tendons in zones

\begin{tabular}{|c|c|c|}
\hline Zone & $\mathbf{n}$ & $\%$ \\
\hline \multicolumn{3}{|c|}{ Flexor } \\
\hline \begin{tabular}{|l|l|}
1 \\
\end{tabular} & 5 & 3.2 \\
\hline 2 & 25 & 16.2 \\
\hline 3 & 13 & 8.4 \\
\hline \begin{tabular}{|l|}
4 \\
\end{tabular} & 8 & 5.2 \\
\hline 5 & 28 & 18.2 \\
\hline T1 & 1 & 0.6 \\
\hline T2 & 6 & 3.9 \\
\hline T3 & 1 & 0.6 \\
\hline \multicolumn{3}{|c|}{ Extansor } \\
\hline $\begin{array}{ll}1 \\
\end{array}$ & 7 & 4.5 \\
\hline 2 & 9 & 5.8 \\
\hline 3 & 3 & 1.9 \\
\hline 4 & 4 & 2.6 \\
\hline 5 & 11 & 7.1 \\
\hline 6 & 21 & 13.6 \\
\hline 7 & 7 & 4.5 \\
\hline 8 & 3 & 1.9 \\
\hline $\mathrm{T} 2$ & 1 & 0.6 \\
\hline T4 & 1 & 0.6 \\
\hline Total & 154* & 100 \\
\hline
\end{tabular}

*: More than one injured zone were present in some patients

The mean of the number of injured tendons was $2.50 \pm 2.26$ tendons (minimum 1- maximum 13). The mean of the number of injured tendons was $2.61 \pm 2.34$ tendons in the male population, while $1.95 \pm 1.78$ tendons in the female population $(\mathrm{p}=0.212)$. One, two, and three tendon injuries were seen in $42.4 \%(n=56), 26.5 \%(n=35), 12.9 \%(n=17)$ of patients, respectively. The mean of the number of injured tendons in the flexor area was $2.57 \pm 2.46$ tendons, in the extensor area was $2.32 \pm 2.03$ tendons, and in both areas was $3.4 \pm 1.34$ tendons.

There were no additional injuries found in 38.6\% $(n=51)$ of patients. It was also more common injury types in both populations. Nerve injuries were seen in $31.8 \%(\mathrm{n}=42)$ of patients as an accompanying injury (Table 4). It was also more common an accompanying injury in both populations. 
Table IV: Frequency and ED cost averages of the accompanying injuries

\begin{tabular}{|c|c|c|c|c|c|}
\hline Group & $\begin{array}{l}\text { Accompanying } \\
\text { injuries }\end{array}$ & $\mathbf{n}$ & $\%$ & $\begin{array}{l}\text { Cost in TL, } \\
(\text { mean } \pm \mathrm{SD})\end{array}$ & $\mathbf{p}$ \\
\hline 1 & Nob,ce,f & 51 & 38.6 & $364,86 \pm 437,65$ & \multirow{8}{*}{$<0.001$} \\
\hline 2 & Nervea,c & 42 & 31.8 & $869,25 \pm 609,26$ & \\
\hline 3 & Nerve+Vessel ${ }^{a, b, d}$ & 17 & 12.9 & $2.141,10 \pm 922,28$ & \\
\hline 4 & Bone ${ }^{c}$ & 14 & 10.6 & $760,89 \pm 726,51$ & \\
\hline 5 & Nerve+Bone ${ }^{a}$ & 5 & 3.8 & $1.305,79 \pm 832,64$ & \\
\hline 6 & Nerve+Bone+Vessela & 2 & 1.5 & $1.320,98 \pm 93,31$ & \\
\hline \multirow[t]{2}{*}{7} & Vessel & 1 & 0.8 & 774,00 & \\
\hline & Total & 132 & 100 & $849,34 \pm 828,90$ & \\
\hline
\end{tabular}

\section{DISCUSSION}

Hands are the most frequently used organs in daily life. Also, injuries of hands are frequent, and tendon injuries saw most of them even in small lacerations. The rate and cost of hands and tendon injuries are increasing day by day in connection with growing industrialization, developing science and technology with the increased use of machinery and tools, and the lack of attention due to workload density and economic stress ${ }^{1,2,7}$.

Tendon injuries affect especially the male population. The proportion of the male population with tendon injuries was reported from $70 \%$ to $91 \%$, and the female population was reported from $8 \%$ to $30 \% 8,9$. Also, the impact of hand injuries accordingly tendon injuries, particularly on the young adult population, leads to significant job loss, as tendon injuries affect the young population, especially in second and third decades ${ }^{1,10,11}$. In our study, male populations were dominant, and most were young adults in our study, like in literature.
The majority of places where hand injuries occur are the home and workplace, agricultural areas, and streets. Oates et al. ${ }^{12}$ reported that $45.4 \%$ in home, $16.2 \%$ in sports, $6.6 \%$ in schools, Trybus et al. ${ }^{2}$ reported that $45.29 \%$ in home, $19.68 \%$ in the workplace, $12.26 \%$ in agriculture areas, $9.6 \%$ in the street, and Gideroglu et al. ${ }^{11}$ reported that $36.06 \%$ in the workplace, $25.4 \%$ in agricultural areas, and $20.98 \%$ in home. In our study, while the home was in first place with $64.4 \%$, the workplace was $18.9 \%$, and the street was $15.2 \%$. The high level of the home and street accidents in our work can be explained by the fact that our hospital is in the residential area.

The etiologies of hand injuries are different according to the places and countries. Ahmad et al. ${ }^{13}$ found that $39 \%$ with glass, $20.8 \%$ with a blade, and $10.8 \%$ chainsaw, Shrihari V ${ }^{14}$ found that $66.74 \%$ crush injury, $18.4 \%$ incision, $10.85 \%$ puncture and $4.29 \%$ avulsion, Sakrak et al. ${ }^{3}$ found that $32.6 \%$ with puncture-cutting tools, $8.5 \%$ with glass, $7 \%$ with the press machine, 6.1\% with an agricultural machine, and $4 \%$ with a saw. In our study, the results were compatible with literature with a high rate of puncture-cutting tools. The most crucial difference in the etiologies in our study was the presence of the animal's bite in 1 case due to uncontrolled street animals and door compression in 5 cases.

The flexor or the extensor area has no distinct superiority in hand injuries. In some studies, the extensor area injuries were more frequent, while the flexor area injuries were more frequent in some studies $1,6,9,15$. In our study, flexor area injuries were more frequent. In our study, flexor zones 5 and 2 and extensor zone 6 injuries were more frequent than others. In literature, flexor zones 2 and 5 injuries were reported as the most frequently injured zone. Zones 3 and 6 were reported as the most frequently injured extensor tendon zones ${ }^{8,16-18}$. 
Gokhan et al. ${ }^{19}$ determined the frequency of isolated tendon injuries as $\% 2.6$, tendon-nerve combination injuries as $3.9 \%$, tendon-artery combination injuries as $11 \%$, tendon, artery, and nerve combination injuries as $16 \%$. Tuncali et al. ${ }^{6}$ determined the frequency of concomitant injuries seen with tendon injuries as $10 \%$. Gideroglu et al. ${ }^{11}$ found the tendon-nerve combination injury frequency as $43.6 \%$, and Keskin et al. ${ }^{1}$ found it $11.3 \%$ and also determined the rate of tendon-artery combination injuries as $4.54 \%$. Ünlü et al..$^{20}$ and Altan et al. ${ }^{21}$ specified that the most frequently injured tissues were tendons $(30 \%, 27 \%$, and $36 \%$ ) in their series. In our study, tendon-nerve combination injuries come in second after the isolated tendon injuries. The reason behind this distinction might be that our patient population consisted of isolated hand injury cases.

A research conducted in the Netherlands established the cost of hand injuries as $\$ 4,4$ million per year. It found that $\$ 2,5$ million of that were hospital costs, and $\$ 1,9$ million were the cost related to the labor loss. Moreover, that study determined the cost of hand and wrist injuries as $\$ 740$ million in total, $\$ 329$ million of that being hospital cost. The cost of hand and wrist injuries per person was established at $\$ 1.235^{22}$. Rosberg et al..$^{23}$ found that the cost of wrist injuries happened in the workplace environment (€22.795) was more than the cost of wrist injuries occurred at home (€15.032) and the cost of complicated injuries (€21.815) was much more than the cost of isolated nerve injuries (€6.562). Trybus et al. ${ }^{2}$ established the total cost average of wrist injuries as $\$ 6.266,76$; $\$ 246,96$ of that $(4 \%)$ being direct cost and $\$ 5.915,80$ of that $(96 \%)$ being indirect cost. Rosberg et al. ${ }^{24}$ determined the average direct cost of hand injuries as $€ 5.255$ and the average indirect cost of them as $€ 10.076$ in another study that was conducted in Sweden.

In our study, the total emergency department cost of patients was 112.116,99 TL and 811,26
TL per patient. The average cost of workplace injuries was 921,85 TL and higher than the others, in line with the recent literature but lacking a statistically significant difference. Similarly, the cost of complicated injuries was higher than isolated tendon injuries. The average cost in our study was lower than in other studies. The reason behind that can be explained like this; we only took emergency room cost into account, and our health cost as a country is generally lower than other countries.

Our patient population is relatively small because it has only consisted of tendon injury cases. Furthermore, we only took ED costs into account and not the further hospital bed costs, following physical therapy costs, and the costs related to the labor loss.

As a result, hand injuries affect the young adult male population, compose $6.6-21 \%$ of all bodily injuries and also compose $10 \%$ of all the ED admissions. However, the ED cost of these injuries is high enough to mind. It is even more evident when further hospital bed costs, following physical therapy costs, and the costs related to the labor loss are added.

Ethics Committee Approval: It was approved by the decision of Istanbul University Cerrahpaşa Faculty of Medicine Ethics Committee No. 39354.

Declaration of Conflicting Interests: The authors declare that they have no conflict of interest.

Financial Disclosure: No financial support was received.

\section{REFERENCES}

1. Keskin D, Seçkin Ü, Bodur $H$, et al. Tendon yaralanmalı hastalarımızın klinik özellikleri. Turk J Phys Med Rehab. 2005; 51: 94-7.

2. Trybus M, Lorkowski J, Brongel L, Hladki W. Causes and consequences of hand injuries. Am J Surg. 2006; 192: 52-7. 
3. Şakrak T, Mangır S, Kormutlu A, ve ark. 1205 El yaralanması olgusunun retrospektif analizi. Turk J Plast Surg. 2009; 17: 134-8.

4. De Jong JP, Nguyen JT, Sonnema AJ, et al. The incidence of acute traumatic tendon injuries in the hand and wrist: a 10-year population-based study. Clin Orthop Surg. 2014; 6: 196-202.

5. Clayton RA, Court-Brown CM. The epidemiology of musculoskeletal tendinous and ligamentous injuries. Injury. 2008; 39: 1338-44.

6. Tuncali D, Yavuz N, Terzioglu A, Aslan G. The rate of upper-extremity deep-structure injuries through small penetrating lacerations. Ann Plast Surg. 2005; 55: 146-8.

7. Mehrzad R, Mookerjee V, Schmidt S, et al. The economic impact of flexor tendon lacerations of the hand in the United States. Ann Plast Surg. 2019; 83: 419-23.

8. Ergüner $\mathrm{H}$, İnanır $\mathrm{M}$, Dursun $\mathrm{N}$, Dursun $\mathrm{E}$. Travmatik el yaralanmalı hastalarımızın klinik özellikleri. Romatol Tıp Rehab. 2002; 132: 43-51.

9. De Jong JP, Nguyen JT, Sonnema AJM, et al. The incidence of acute traumatic tendon injuries in the hand and wrist: A 10-Year Population-based Study. Clin Orthop Surg. 2014; 6: 196-202.

10. Uludağ A, Tosun HB, Çiçek N, ve ark. Yaralanma sonrası ekstremitelerin yumuşak dokusunda gözlenen yabancı cisimlere cerrahi yaklaşım. Dicle Med J. 2019; 46: 215-23.

11. Gideroğlu K, Sağlam İ, Çakıcı H, ve ark. Bolu yöresel el yaralanmalarının epidemiyolojisi retrospektif klinik çalışma. Abant Med J. 2012; 1: 135.

12. Ootes D, Lambers KT, Ring DC. The epidemiology of upper extremity injuries presenting to the emergency department in the United States. HAND. 2012; 7: 18-22.

13. Ahmad M, Hussain SS, Tariq F, et al. Flexor tendon injuries of hand: experience at pakıstan institute of medical sciences, Islamabad, Pakıstan. J Ayub Med Coll Abbottabad. 2007; 19: 6-9.

14. Shrihari V. Spectrum of hand injuries and their management at a tertiary care hospital using the hand injury scoring system. Int Surg J. 2016; 3: 1761-66.

15. Aslan A, Aslan İ, Özmeriç A, ve ark. Acil el yaralanmalarında deneyimlerimiz: 5 yıllık verilerin epidemiyolojik değerlendirmesi. TAF Prev Med Bull. 2013; 12: 563-70.

16. Kitsis CK, Wade PJF, Krikler SJ. Controlled active motion following primary flexor tendon repair: A prospective study over 9 years. J Hand Surg. 1998; 23B: 344-9.

17. Nassab R, Kok K, Constantinides J, Rajaratnam V. The diagnostic accuracy of clinical examination in hand lacerations. Int J Surg. 2007; 5: 105-8.

18. Brug E, Langer M, Probst A. Flexor and extensor tendon injuries of the hand. Orthopade. 2000; 29: 216-27.

19. Gökhan S, Altuncı YA, Orak M, Üstündağ M, Söğüt Ö, Özhasenekler A. Hand and wrist injuries caused by glass cuts: Accidental or due to sudden Anger? Tr J Emerg Med. 2011; 11: 54-8.

20. Ünlü RE, Ünlü EA, Orbay H, Şensöz Ö, Ortak T. Ezici el yaralanmaları. Ulus Travma Acil Cerrahi Derg. 2005; 11: 324-8.

21. Altan L, Akın S, Bingöl Ü, Özbek S, Yurtkuran M. El Yaralanması ciddiyet skoru'nun endüstriyel el yaralanmalarında prognozu belirlemedeki rolü. Ulus Travma Acil Cerrahi Derg. 2004; 10: 97-101.

22. de Putter CE, Selles RW, Polinder S, et al. Economic impact of hand and wrist injuries: Healthcare costs and productivity costs in a populationbased study. J Bone Joint Surg Am. 2012; 94: e56.

23. Rosberg HE, Carlsson KS, Cederlund RI, Ramel E, Dahlin LB. Costs and outcome for serious hand and arm injuries during the first year after trauma - a prospective study. BMC Public Health. 2013; 13: 501.

24. Rosberg HE, Carlsson KS, Hojgard S, et al. What determines the costs of repair and rehabilitation of flexor tendon injuries in zone II? A multiple regression analysis of data from southern Sweden. Hand Surg [Br]. 2003; 28: 106-12. 